\title{
Ernst Cassirer: O mito do Estado e o Direito
}

Filipe Natal de Gaspari

CASSIRER, E. O mito do Estado. São Paulo: Códex, 2003.

\section{Resumo}

Esta resenha se propõe a analisar a obra $O$ mito do Estado, de Ernst Cassirer, sob o prisma do Direito. A noção de justiça é vista pelo autor como um dos elementos cruciais que integram a luta da história do pensamento contra a ascensão do Estado em sua versão mítica.

Palavras-chave: O mito do Estado - Totalitarismo - Ernst Gassirer - Justiça. 
Em $O$ mito do Estado, o método de investigação de Ernst Cassirer tem a virtude de trazer, logo de início, uma tentativa de reconciliação do mito com o campo do conhecimento filosófico. Segundo Cassirer, o mito não havia sido apenas marginalizado na história do pensamento, não havia sido tratado apenas como manifestação cultural de segunda grandeza: narram-se, na obra, os termos de uma verdadeira batalha, encampada por diversos pensadores, a fim de opor o mito ao "verdadeiro saber". A narrativa mítica seria o avesso da investigação filosófica: aquela, secundária, cega e infantil; esta, elementar e libertadora, reflexo inconteste da maturidade racional dos seres humanos.

A altura teórica, contudo, de $O$ mito do Estado, espelha-se no esforço de mostrar que, embora de um ponto de vista crítico seja possível constatar uma tentativa sistemática de se rebaixar o mito, a filosofia jamais conseguiu escapar, por completo, de todos os dilemas impostos pelas suas inúmeras formas de manifestação. Como se verá mais adiante, a exemplo da ascensão sem precedentes do totalitarismo no início do século $\mathrm{XX}$, a total racionalização das manifestações culturais, desiderato de um grande número de pensadores consagrados, foi uma empreitada, em boa medida, fracassada.

Colocado esse panorama geral ${ }^{\mathrm{I}}$, a seguir quero tratar da relação específica entre a obra e o Direito. Cassirer leva o leitor a compreender que o ponto de toque destes se encontra na constatação de que a construção do ideal de justiça é uma das principais linhas de frente da batalha da história do pensamento contra o mito.

O autor observa que Platão, no Górgias, ao apresentar os três elementos que compõem a sua noção de ética, quais sejam, logos, nomos e taxis (razão, legalidade e ordem), está em busca da construção de um conceito de justiça. A justiça, para Platão, é a tradução da "ideia do bem", da verdade em si. Ela é revelada pela razão. Em contrapartida, o mito, encarnado na ideia de exaltação das façanhas dos guerreiros e dos heróis, encontra-se limitado ao mundo empírico e à tradição. Ao contrário da razão, a tradição amarra o homem e impede o seu avanço (CASSIRER, 2003). Ao aplicar esse sistema teórico mais amplo à compreensão do Estado, desponta em Platão a noção de Estado legal vale dizer, vinculado pelo ideal de justiça - em oposição ao Estado arbitrário, de contornos míticos (CASSIRER, 2003).

Na Idade Média, segundo Cassirer, deu-se a transição do paradigma do Estado legal grego para o cristão. A crença nos potenciais da razão humana,

I Sobre aspectos gerais da obra, ver a interessante resenha de Leo Strauss em seu What is political philosophy? (STRAUSS, I992, p. 292-296). 
presente nas obras de Santo Agostinho e São Tomás de Aquino, fez escola. A razão equipara os homens da mesma forma que Deus ama cada um de seus filhos. Com a inserção do ideário cristão, a máxima de que perante o Estado "todos os homens são livres e iguais por força da razão" foi traduzida para o princípio de que "todos os homens são livres e iguais pela graça de Deus" (CASSIRER, 2003, p. I32). Nos dois casos, o direito natural, ora de matiz mormente racionalista, ora com contornos teológicos, aparece como fator de limitação externa da ação dos estadistas.

Foi, porém, no século XVIII que o ideal de limitação do Estado apareceu com toda a sua magnitude. Como observa Cassirer, de Hobbes aos iluministas, o método dos teóricos do contrato social não era o histórico. Em verdade, as categorias manejadas por tais pensadores, como o estado de natureza, eram postulados analíticos, de caráter estritamente racional. Por meio dessa forma de pensar, a crença nos potenciais da racionalidade humana é novamente colocada em destaque pela teoria política. Se é certo que o contrato, pelo processo de autovinculação, pressupõe o exercício da razão e da liberdade, não é lógico, assim, que quem pactue possa abdicar, por ato próprio, dos direitos que justificam o ato de vinculação inicial.

É justamente de tais referenciais teóricos que decorre a assunção da existência de direitos pré-contratuais, que nascem com o homem pela simples potencialidade de este ser um ente racional. Tem-se, pois, a formação de uma referência de justiça: o indivíduo pode opor direitos ao Estado, como a razão se opõe ao mito e à tradição. Essa é a inspiração do "racionalismo político", base das declarações de direitos engendradas no final do século XVIII, como observa Cassirer da análise do texto da Constituição norte-americana e da Declaração de Direitos francesa (CASSIRER, 2003).

Não obstante, em $O$ mito do Estado Ernst Cassirer observa que o século XIX marca o período da grande queda da construção do Estado como ente vinculado pela ideia de justiça. Cassirer atribui essa tendência tanto ao insucesso prático da aplicação das ideias iluministas como à tentativa de afirmação dos povos germânicos na cena política europeia. Nesse cenário, o pensamento iluminista passa a ser vítima de graves críticas pelos teóricos do idealismo romântico alemão. Cassirer identifica uma tendência de modificação radical do método de se encarar a realidade: trata-se da batalha entre o "idealismo crítico" de Kant e o "idealismo mágico" de românticos como Schlegel e Schelling (CASSIRER, 2003). Em lugar dos postulados críticos da razão, a tradição e o Estado, como elementos míticos, seriam colocados, respectivamente, no patamar de guia dos povos e de ente supremo, capazes de aferir a validade da ação política e conferir significado pleno aos fatos do mundo. 
No século XIX, o exemplo máximo do paradigma de Estado alheio à limitação imposta por uma noção de justiça pode ser identificado no sistema de pensamento de Hegel (CASSIRER, 2003). Na compreensão de Cassirer, Hegel provocou uma mudança radical no método filosófico ao eleger o Estado como pressuposto de toda a verdade. Em Hegel, não há história nem verdade para além do Estado. Ao mesmo tempo, sua teoria opera a destituição do Estado de qualquer moralidade. Ora, se o Estado é toda a história, se o poder deste confere significado às ações do mundo e se ele é despido de qualquer componente moral, logo, a história e as ações prescindem de qualquer limitação de ordem valorativa. Nessa forma de pensar, fica difícil falar em direitos oponíveis ao Estado, já que este tem o condão de revelar todas as regras válidas a serem seguidas pelo corpo social.

Cassirer é consciente o bastante para reconhecer que atribuir apenas aos românticos - ou mesmo a Hegel - a responsabilidade pela ascensão do totalitarismo no começo do século XX seria absurdo. No entanto, por mais que o referido autor se disponha a tentar isentá-los de uma ligação mais direta com essa tendência, afirmando terem sido as ideias de Hegel e dos românticos vitimadas pela má compreensão de parte de seus leitores, é inegável que, em tais autores, encontramos a deixa perfeita para a construção de um paradigma de Estado com inclinações míticas. Em certa altura da obra, o próprio Cassirer se refere à possível e frequente perda da individualidade histórica dos trabalhos filosóficos: até que ponto uma obra não existe também em razão da compreensão de quem a lê? Leitura decaída ou não, o fato é que, de braços dados com outros elementos de ordem política e econômica, o pessimismo romântico e a teoria hegeliana da potência do Estado encaixaram-se perfeitamente na lacuna deixada pelo lugar outrora ocupado por uma noção transcendente de justiça e pela ideia de limitação do poder do Estado pela existência de direitos inatos ao homem.

Um estudo acurado do livro nos leva a compreender que o mito não desapareceu completamente em nenhum período da história da humanidade. A obra revela que o conflito da Segunda Grande Guerra, para além das trincheiras do campo de batalha e da cena política, deu-se igualmente no âmbito da cultura, da subversão da noção de Estado e de Direito. Agora, independentemente da extensão indesejável tomada pelos movimentos antiliberais no começo do século XX, extirpar o mito do nosso campo de visão seria uma pretensão ingênua. A proposta de reconciliação de Cassirer com o mito guarda, antes de mais nada, uma premissa normativa: é preciso considerar a sua magnitude, compreendê-lo, conferir-lhe a medida devida para poder controlá-lo. Nesse âmbito, a construção da ideia de justiça aparece como um elemento 
importante de contenção do mito do Estado. Da mesma forma que, no campo da reflexão filosófica, a razão se opõe ao mito, na teoria política o Estado limitado se opõe ao arbitrário.

\section{Referências}

CASSIRER, E. O mito do Estado. São Paulo: Códex, 2003.

STRAUSS, L. What is political philosophy? London: The University of Chicago Press, I992.

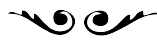

Filipe Natal de Gaspari é graduando em Direito pela Pontifícia Universidade Católica de São Paulo. gasparifilipe@gmail.com 